\title{
Measurement of Innovative Performance of Selected Economies of the European Union and Switzerland
}

\author{
Ingrid Majerová
}

\begin{abstract}
Currently, the focus is on innovation as key component of competitiveness of economies. Innovation cannot be understood only as the introduction of new products and production processes, but also as an application of changes in work organization and management, or new ways of selling products. Innovative performance is related not only to the ability of firms, but is also bound to the environment of the entire national system that includes a system of public and private institutions. This article aims to find innovative performance of selected economies of the European Union, namely the Czech Republic, Poland, Austria and Germany and one country outside the EU - Switzerland and confirm the hypothesis of a direct relation of innovativeness and the size of the economy. The methods of description, analysis and comparison were used in the article, and innovative performance was measured through three innovation indexes in the period 2001 to 2009.
\end{abstract}

Index Terms - comparison, competitiveness, Global Innovation Index, innovation, Summary Innovation Index.

\section{INTRODUCTION}

Innovation is essential for the competitiveness of countries and regions [1]. Innovations are the key to improving competitiveness, economic growth and employment as well [2]. The level of economic productivity of the country affects the set of institutions, policies, internal and external factors. States are intermediaries who influence how firms can be competitive. Because it is increasingly difficult for companies to compete based on price factors (the factors of production), they must try to produce with high share of knowledge. The role of knowledge, especially in terms of innovation, is for maintaining of the productive economy vital and enables companies from developed countries have to face competition from developing economies to succeed in globalized markets.

Firms must increasingly compete with unique productions, specific know-how and innovation. They must transfer its activities to research and knowledge-intensive productions that feature innovative rhythm and require high skills and adaptability of the labor force [3].

\footnotetext{
Manuscript received February 10, 2014; revised April 10, 2014. This paper was supported by the project OPVK Innovation of study programs at the Silesian University, School of Business Faculty in Karviná, project registration number CZ.1.07/2.2.00/28.0017.

Ingrid Majerová is with the Department of Economics, Silesian University in Opava, School of Business Administration in Karviná, Univerzitní náměstí 1934, 73401 Karviná, Czech Republic (e-mail: majerova@opf.slu.cz).
}

\section{INNOVATION AND ITS TYPES}

In the basic sense of the word innovation concerns the search and discovery, experimentation, development, imitation and adoption of new products, new production and organizational processes [4]. The definition of innovation is diverse and there are also different types of innovation.

\section{A. Definition of Innovation}

The idea of a lonely scientist in a laboratory for exploring new things and its applied directly to the production of a new product is no longer considered a real form of innovation. Innovation is not a synonym of the invention it is a process that requires much more than just "inventing" because it includes all the individual process steps prior to the start of production of the product or the service. Therefore, the implementation and introduction is an important part of the innovation [5]. Innovation must increase the value of the product due of positive change, it must be substantially different. As a result, productivity is improved as the basic source for the growth of wealth of the economy [6]. Josef Schumpeter created and popularized the economic theory of creative destruction and the theory of innovation and progress [7].

According to [8] innovation is thus defined as:

1) The introduction of new products that are not yet familiar to the consumers or are completely new quality

2) The introduction of new methods of production, which may not be based on new scientific discoveries, but may lie in a new way of commercial processing of the commodity

3) Opening of a new market, a market on which a specific sector of the country has not yet entered

4) Obtaining new source of supply of raw materials or semi-finished again regardless of whether this source already exists or whether it must be first created.

5) Implementation of a new organization of industry, such as the creation of a monopoly position (for example through the creation of trusts), or its disintegration.

Schumpeterian doctrine does not match with neoclassical and Keynesian economics in this point. In Keynes' theories independent sources, such as technology, innovation, knowledge and business are affected by the policy. On the contrary, Schumpeter gave these independent sources to centers of economic growth model. From the neoclassical perspective, innovations are exogenous ones, they cannot be influenced by economic policies. Everything is focused on the efficient allocation of scarce resources to correct price signals. However, according to Schumpeter, the main drivers of economic growth are efficiency of productivity and adaptively. Individuals, as well as individual economies are 
the main actors of this process.

Productivity growth in the U.S., which has occurred in recent decade, is not the result of the accumulation of capital, but rather the result of innovation. The U.S. economy has developed new technologies such as information and communication technology, and applied them on a large scale [9]. Capital was not the production factor that determined the direction, but on the other hand, there was a need to invest in these technologies. Consequently, it appeared innovative gap between the USA and Europe. This view of innovation as a source of economic growth received adequate attention in the last decade, and it is because innovation provides basis for explaining and promoting economic growth to policy makers and economists in knowledge-based economies.

\section{B. Types of Innovations an Creativity}

After defining the concept of innovation is necessary to explain the different types of innovation. Each type has its own characteristics and consequences that should be taken into account to obtain competitiveness in the globalizing market nowadays. [10] distinguishes four types of innovation:

1) Architectonic and component (modular) innovations include a change in one or more components of a product system without significant changes in the overall design. Architectonic innovations change the overall design of the system or a way to connect components.

2) Eligibility strengthening and reducing innovations - the eligibility strengthening innovations are based on existing knowledge-based companies, while eligibility reducing innovations cause obsolescence of companies.

3) Radical and incremental innovations - the radical innovations lie in the degree of difference from the previous existing product or process. Incremental innovations involve only a small change (or modification) of the current state.

4) Product and process innovations - product innovations are part of the goods and services, process innovations lie in the way of business, such as in the techniques of production or marketing of goods and services.

All innovation starts by creative ideas. Innovations defines [11] as the successful implementation of creative ideas within (some) organizations. From this perspective, the creativity of individuals and teams is the starting point for innovations: the first is a necessary but not sufficient condition for the second. Creativity is an important input for innovations, but is not identical thereto. Creativity involves the process of creating new ideas and concepts, or amends an existing ones, innovation involves the use of these ideas and concepts. These two concepts are closely related, and that the subjects were competitive, they must be creative and innovative at the same time. And we are back with Schumpeter - the economic theory of creative destruction describes how the usual methods of "doing things" are destroyed and replaced with new ones. Creativity serves as a driving force for recombination of elements to provide new services and products, which ultimately leads to economic growth. Creativity and design are important elements of an advanced knowledge economy; they promote innovations and have a positive impact on people's health and business performance.

\section{MEASUREMENT OF INNOVATIVE PERFORMANCE}

Innovations cannot be understood only as the introduction of new products and production processes, but also as an application of changes in work organization and management or new ways of selling products. Innovative performance is related not only to the ability of firms, but is also connected to the environment of the entire national system that includes a system of public and private institutions. Their activities and links arrange for the production, transmission and use of new knowledge and its consistency and continual interactions are important for the functioning of the national innovation system. Important role in the innovation process play not only companies, suppliers and customers, but also universities and research institutes and undoubtedly the quality of institutions and the environment in which the innovation process is carried out.

Several international institutions try to capture and measure the innovative performance. Currently there are three different methods: one is Summary Innovation Index (SII), which is compiled on the level of the European economies and two Global Innovation Indexes (GII) - Global Innovation Index compiled by Boston Consulting Group (BCG), in cooperation with the National Association of Manufacturers (NAM) and the Global innovation Index introduced by Institut Européen d'Administration des Affaires (INSEAD) and World Intellectual Property Organization (WIPO). The last two indexes are prepared in recent years, their time series do not correspond to our analysis period, therefore, will be presented only for information and the SII index will be then focused.

\section{A. Global Innovation Indexes}

The first analyzed the global innovation index, which measures the degree of innovation economy, was created jointly by BCG and associations NAM in 2009 [12] (see. GII (mark it as $\mathrm{GII}_{\mathrm{BN}}$ ) is part of research studies that explore how the results of innovation at the company level and the ability of governments to promote and support innovations through public policy. The study includes a survey of more than 1.000 senior executives from NAM member companies across all industries, interviews with directors, and comparison of the "innovation friendliness" of the 110 countries and 50 U.S. states.

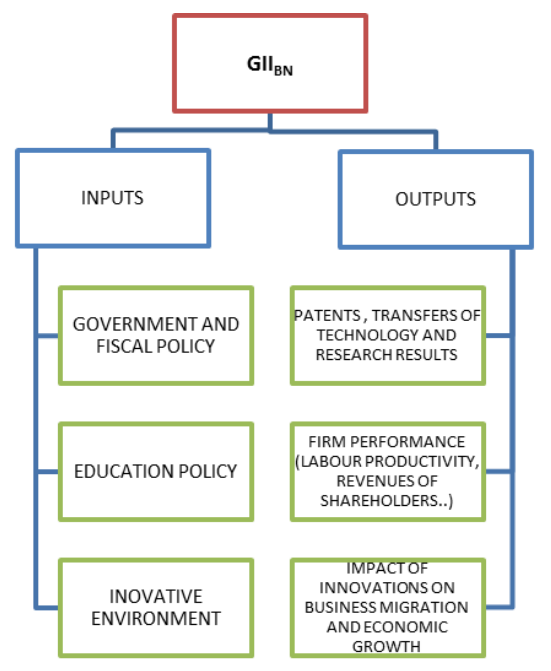

Fig. 1. Structure of global innovation Index $\mathrm{GII}_{\mathrm{BN}}$. 
This index includes not only the performance of individual economies, but also the activities of firms leading to innovation and best practices. It also focuses on new political innovation indicators, including tax incentives, immigration, education and intellectual property. $\mathrm{GII}_{\mathrm{BN}}$ is formed both innovative inputs and innovative outputs (see Fig. 1).

Second Global Innovation Index (let's call it $\mathrm{GII}_{\mathrm{IW}}$ ) is produced by high school INSEAD and WIPO and has been used since 2007. Like the previous index it is divided into input and output sub-indexes, their weight is equally distributed in the calculation (see Fig. 2). There are five sub-indexes of input, two of output. Inputs are indicators that allow the economy to stimulate innovations and outputs are the results of innovative activities in the economies. The choice of variables is a combination of qualitative and quantitative data based on the statistics of the World Economic Forum (only qualitative data), the World Bank and the International Telecommunication Union. It examines 90 indicators in 130 economies (in 2009).

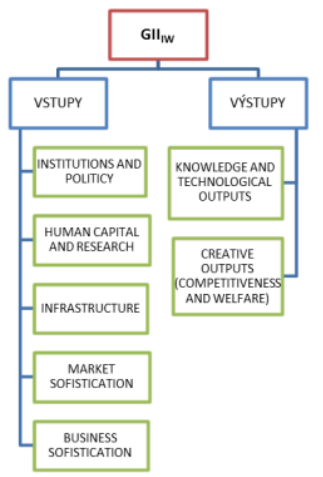

Fig. 2. Structure of global innovation Index GII Iw.

The selected economies (Czech Republic, Germany, Poland, Austria and Switzerland) will now be compared based on the two indexes. As already mentioned, the history of indexes is short, introduction is not yet checked for viability and using the input data is also questionable. The first index is in use since 2009 , the second since 2007 , but which has missed one year - 2008, and because of the crisis [13], so only the year 2009 will be compared. GII $_{\mathrm{BN}}$ uses for its assessment scale four ranges: $\geq 1,\{0.99-0\},\{0-(-0.99)\} \leq$ and (-1) GIIIW uses interval $\{0-5\}$. The evaluation results are shown in Table I. Decimals indicate the score, the numbers in parentheses placement of individual economies.

TABLE I: THE COMPARISON OF ECONOMIES IN THE GLOBAL INNOVATION INDEXES IN 2009

\begin{tabular}{lrcc}
\hline \hline Countries & GII $_{\mathrm{BN}}$ & $\mathrm{GII}_{\mathrm{IW}}$ & difference \\
\hline Czech Republic & $0.41(32)$ & $3.64(33)$ & no \\
Germany & $1.12(\mathbf{1 9})$ & $4.99(\mathbf{2})$ & yes \\
Poland & $-0.12(52)$ & $3.15(56)$ & min \\
Austria & $1.15(17)$ & $4.46(15)$ & no \\
Switzerland & $2.23(\mathbf{3})$ & $4.73(\mathbf{7})$ & yes \\
\hline Number of countries & 110 & 130 & \\
\hline \hline
\end{tabular}

In the above comparison is surprising vastly different result of Germany and the different position of Switzerland. While the first index ranks Germany to nineteenth place of one hundred and ten economies, in the second index is Germany regarded as the second most competitive economy in the world (behind the U.S., of course). In the case of
Switzerland is the situation opposite - if in the first index is this country third in the world, second index ranks it to seventh place (behind Germany). For other countries, the results of both indexes are comparable. With these results thus related issue, the extent to which the measurement of innovativeness of economies is meaningful and which indexes can thus help to investors and other economic subjects.

\section{B. Summary Innovation Index}

The main tool for comparison between innovation environment and innovation performance of national economies in Europe is the Summary Innovation Index (SII), which is compiled since 2001 and is published in the European Innovation Scoreboard (EIS). This newsletter began to be published under the Lisbon European Council in 2000 and provides a comparative analysis of innovation indicators for monitoring progress towards the EU to become the most competitive and dynamic knowledge-based economy in the world, capable of sustainable economic growth with a quantitative and qualitative increase in jobs and greater social cohesion. The SII is one of the composite (aggregate) indicators that summarize the data of two or more individual indicators (indicators of innovation, science and research) and allow take into account the multidimensional nature of innovation performance.

According to the [14] SII consists from overview of the national innovation performance of European economies and according to the results countries are divided into four large groups:

1) Innovative leaders - their innovation performance is above the EU average (Switzerland and Germany)

2) Innovation followers - their innovation performance is below the leaders, but above the EU average (Austria)

3) Average innovators - their innovation performance is below the EU average

4) Catching-up economies - their innovation performance, is below the EU average, but the growth rate in terms of innovation is above the EU average (Czech Republic, Poland).

Average innovators are a new group, the last two groups formed catching-up economies to the 2007 (with the same characteristics) and losing economies that were below the EU average and even their innovation growth was not satisfactory (Turkey and Romania were here included) [15]-[17].

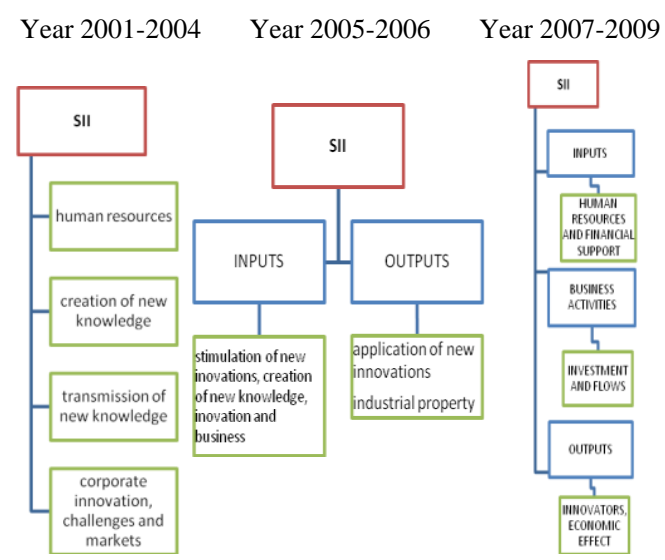

Fig. 3. Indicators of SII in the years 2001-2009. 
Like division of innovative economies in the group, a structure of the index recorded the substantial changes over time that were caused by changing innovation environment and the effects in the national economies, but also in the global economy. Although, there were two changes in the design of indicators SII in the monitored period (See Fig. 3), in each newsletter the possibility of comparison of individual years is declared. This assumption is also accepted and the economies are compared in the monitored period.

Values of Summary Innovation Index range between $\{0-1\}$, the closer the value of one, the economy has a greater ability to produce and innovate. The methodology for calculating this index is used by [18] and shown in (1) and (2):

$$
S_{i}=\frac{\sum_{j=1}^{m} q_{j} y_{i j}}{\sum_{j=1}^{m} q_{j}}
$$

where

$$
y_{i j}=\frac{x_{i j}-\min x_{j}}{\max x_{j}-\min x_{j}}
$$

$x_{i j}$ is the value of indicator $j$ for country $i, q_{i}$ is the weight of indicator $j$ in index a $y_{i j}$ is the value of revised indicator of economy $i$.

The development of this index SII in selected economies in the monitored period is shown in Table III. Year 2001 is for the then candidate countries Czech Republic and Poland only simulation, on the basis of the unavailability of SII [19]. Other data were drawn from [15]-[17], [20]-[26].

TABLE III: SUMMARY INNOVATION INDEX OF SELECTED ECONOMIES IN THE YEARS 2001-2009

\begin{tabular}{lccccc}
\hline \hline Countries & 2001 & 2002 & 2003 & 2004 & 2005 \\
\hline Czech Republic & 0.27 & 0.31 & 0.31 & 0.31 & 0.33 \\
Germany & 0.60 & 0.60 & 0.60 & 0.60 & 0.60 \\
Poland & 0.10 & 0.20 & 0.20 & 0.21 & 0.21 \\
Austria & 0.47 & 0.47 & 0.48 & 0.48 & 0.48 \\
Switzerland & 0.69 & 0.69 & 0.70 & 0.71 & 0.69 \\
\hline Countries & 2006 & 2007 & 2008 & 2009 & \\
\hline Czech Republic & 0.34 & 0.39 & 0.40 & 0.42 & \\
Germany & 0.59 & 0.57 & 0.58 & 0.59 & \\
Poland & 0.22 & 0.29 & 0.31 & 0.32 & \\
Austria & 0.48 & 0.52 & 0.53 & 0.54 & \\
Switzerland & 0.69 & 0.66 & 0.68 & 0.69 & \\
\hline \hline
\end{tabular}

\section{CONCLUSION}

The results of the innovative performance analyzed in this paper are not surprising and reflect a general idea of the innovativeness of the economies - Switzerland is in a leading position, followed by Germany that is followed closely by Austria in the last three years. The Czech Republic is in innovative activity successful from less than half (42\%),
Poland of one third. While Switzerland and Germany maintain the same level steadily, the greatest progress was achieved by Poland (improving results of the innovation capacity more than $20 \%$ in the monitored period), Czech Republic (15\% improvement) and the aforementioned Austria by seven percent.

The above results therefore do not confirm the hypothesis of a direct relation of the innovation economy and its size, as the smallest economy was monitored as the most innovative and the largest economy was ranked in the second position. The second largest economy - Poland is lagging behind in innovation in all surveyed economies.

\section{REFERENCES}

[1] K. Skokan, "Systémy inovací v regionálním rozvoji," Ekonomická revue 2005, vol. 8, no. 4, pp. 12-25, 2005.

[2] P. N. Cooke, P. Boekholt, and F. Todlin, The Governance of Innovation in Europe. Regional Perspectives on Global Competitivenes, Bath: The Bath Press, 2000.

[3] J. Sereghyová, "Konkurenceschopnost Evropské unie v podmínkách globalizace," Acta Oeconomica Pragensia, vol. 12, no. 3, pp. 143-168. 2004.

[4] G. Dosi, "The nature of the innovative process," in Dosi, G, Freeman, C. et al. eds., Technical Change and Economic Theory, London: Pinter Publishers, 1988.

[5] L. Mohr, "Determinants of innovation in organizations," The American Political Science Review, vol. 63, no. 1, pp 111-121, 1969.

[6] J. A. Schumpeter, "The analysis of economic change," The Review of Economics and Statistics, vol. 17, no. 4, pp. 2-10, 1935.

[7] H. Reinert and E. S. Reinert, "Creative destruction in economics: Nietzsche, sombart, schumpeter," The European Heritage in Economics and the Social Sciences, vol. 3, pp. 55-85, 2006.

[8] J. A. Shumpeter, The Theory of Economic Development, Boston: Harvard University Press, 1934.

[9] H. K. Stiroh, "Information technology and productivity: Old answers and new questions," CESifo Economic Studies, vol. 54, no. 3, pp. 358-372, 2008.

[10] M. Shilling, Strategic Management of Technological Innovation, Paperback: McGraw-Hill/Irwin, 2005.

[11] T. M. Amabile, Creativity in Context: Update to the Social Psychology of Creativity, Boulder, CO: Westview, 1996.

[12] J. P. Andrew, E. Stover DeRocco, and A. Taylor, The Innovation Imperative in Manufacturing: How the United States Can Restore Its Edge, Boston: Boston Colsunting Group, 2009.

[13] INSEAD. (2008-2009). Global Innovation Index. [Online]. Available: http://www.globalinnovationindex.org/userfiles/file/GII-2008-2009-R eport.pdf.

[14] European Commision, European Competitiveness Report 2010, Commission Staff working document, 2010.

[15] EC, European Innovation Scoreboard, Belgium: European Communities, 2007.

[16] EC, European Innovation Scoreboard, Belgium: European Communities, 2008.

[17] EC, European Innovation Scoreboard 2008: Comparative analysis of innovation performance, Belgium: European Communities, 2009.

[18] H. Hollanders and A. Arundel. European Innovation Scoreboard. Methodology Report. European Commision. [Online]. Available: http://arno.unimaas.nl/show.cgi?fid=15494.

[19] CORDIS. Simulated Innovation Scoreboard 2001 for Six Candidate Countries. [Online]. Available: http://cordis.europa.eu/itt/itt-en/01-6/innov05-graph.htm.

[20] EC, European Innovation Scoreboard, Belgium: European Communities, 2001.

[21] EC, European Innovation Scoreboard, Belgium: European Communities, 2002.

[22] EC, European Innovation Scoreboard, Belgium: European Communities, 2003.

[23] EC, European Innovation Scoreboard, Belgium: European Communities, 2004.

[24] EC, European Innovation Scoreboard, Belgium: European Communities, 2005

[25] EC, European Innovation Scoreboard, Belgium: European Communities, 2006. 
[26] EC, European Innovation Scoreboard 2009: Comparative analysis of innovation performance, Belgium: European Communities, 2010.

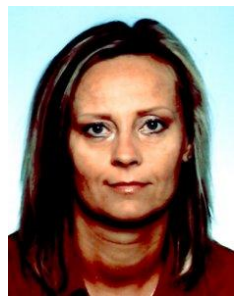

Ingrid Majerová was born in Karviná, Czech Republic, on 9th May 1971. She graduated her master studies at the Faculty of Economics, VSB-Technical University of Ostrava, Czech Republic in the field of national economy in 1994. In 1998 she received a doctoral degree therein, in the field of economics.

She worked in the private sector as an economist and head of management from 1997 to 2002. In 2004 she began working as an assistant professor at the Silesian University, Faculty of Business Administration, Czech Republic, where at the Department of Economics she works to this day. Her most important publications include: "Least Developed Countries in Indexes of Human Development and Poverty," in Proc. of the 18th IBIMA Conference Innovation and Sustainable Economic Competitive Advantage: From
Regional Development to World Economies. Norristown, 2012, pp. 1210-1224, "International Development Cooperation of the Czech Republic in the Context of European Development," Prague Economic Papers, vol. 2. pp. 166-185, June 2012, "International Development Cooperation of the Czech Republic: a Comparison with new EU-Donors," in Tvrdon, M. and I. Majerova (eds.), Proc. of the 10th International Conference Economic Policy in the European Union Member Countries, Karviná, 2013, pp. 208-218. She specializes in the area of international economics, problems of developing countries and international development assistance.

Dr. Majerová was a member of the organizing and program committees of several international conferences such as the International Scientific Conferences Economic Policy in the European Union in the years 2009-2013, International Scientific Conference IBIMA 2013 in Vienna and was coeditor of a major Proceedings of International Scientific Conference Economic Policy in the European Union 2012. 